\title{
MITOS DI BALIK LAPORAN SOSIAL BANK SYARIAH
}

\author{
ARY YUNITA ANGGRAENI ${ }^{1)}$ \\ EKO GANIS SUKOHARSONO ${ }^{2)}$ \\ M. ACHSIN ${ }^{2)}$ \\ Universitas Merdeka Malang \\ ${ }^{2)}$ Universitas Brawijaya \\ *Email : aaryyunita@gmail.com
}

\begin{abstract}
This study aims to understand and interpret the social reports of one of the first Islamic banks in Indonesia contained in the annual report. The analytical tool used in this study is Barthes's semiotics through the stages of interpretation in a denotative and connotative manner. Interpretations made by researchers other than the text also include visual interpretations. In this study it was found that there were inconsistencies in the preparation of social reports, and there were texts and images which aimed to create, build and maintain the positive side of the company in the eyes of the public.
\end{abstract}

Keywords: Social reports, text interpretation, and Barthes semiotics.

\section{PENDAHULUAN}

Business cannot be succesful when the society around them fails ungkapan yang lahir dari Responsible Business Summit di tahun 2013 ini tentunya dapat menjadi pedoman para pebisnis dalam menjalankan usahanya. Lingkungan sekitar perusahaan merupakan lingkungan yang terdekat serta dapat menimbulkan dan merasakan dampak dari aktivitas perusahaan. Melalui program Corporate Social Responsibility (CSR), perusahaan berusaha menjembatani kepentingannya dengan lingkungan sekitar agar dapat menghasilkan keuntungan bagi kedua belah pihak.

"CSR atau akuntansi sosial dan lingkungan (yang kita ketahui juga sebagai corporate sosial responsibility reporting, non-financial reporting, atau sustainability accounting) adalah proses pengkomunikasian dampak sosial dan lingkungan dari aktivitas ekonomi organisasi kepada beberapa kelompok tertentu dalam suatu lingkungan," Sukoharsono, 2010:2, yang biasanya tersaji dalam laporan tahunan perusahaan. Laporan ini bertujuan untuk menunjukkan kepada masyarakat bahwa perusahaan juga concern terhadap lingkungan dan sosial. Penekanan terhadap sisi lingkungan dan sosial ini mempunyai potensi untuk memerluas dan menaikkan citra perusahaan dan peluang pasar, di sisi lain juga memperkuat kepercayaan masyarakat terhadap perusahaan. Selain perusahaan, pemerintah juga menaruh perhatian terhadap CSR, hal ini ditunjukkan dengan diterbitkannya peraturan mengenai kewajiban praktik dan 
pengungkapan CSR melalui Undang-Undang No. 40 Tahun 2007 yang menyebutkan, "tanggung jawab sosial dan lingkungan adalah komitmen perseroan untuk berperan serta dalam pembangunan ekonomi berkelanjutan guna meningkatkan kualitas kehidupan dan lingkungan yang bermanfaat, baik bagi perseroan sendiri, komunitas setempat maupun masyarakat pada umumnya". Seperti yang diungkapkan oleh Priyanti (2012), bahwa "CSR bukan semata-mata untuk mendapatkan ijin sosial dari masyarakat untuk melindungi operasional perusahaan atau untuk mengurangi efek negatif lingkungan dari aktivitas usahanya, tetapi lebih jauh CSR adalah upaya untuk meningkatkan mutu hidup bersama, maju bersama seluruh stakeholder". Meminjam istilah dari ilmu hayat, perusahaan dan masyarakat seharusnya mempunyai hubungan simbiosis mutualisme, dimana masyarakat dan perusahaan saling menguntungkan, namun pada prakteknya hal tersebut belum terjadi. Seperti yang diungkapkan oleh Sayekti dan Wondabio (2007) bahwa untuk membangun, mempertahankan dan melegitimasi kontribusi perusahaan dari sisi ekonomi dan politis salah satu caranya adalah perusahaan perlu mengungkapan informasi corporate social responsibility dalam laporan tahunannya.

"Perusahaan publik di Indonesia telah banyak melakukan praktik pengungkapan CSR. Secara umum praktek CSR lebih banyak dilakukan oleh perusahaan manufaktur maupun tambang, namun, seiring dengan adanya tren global akan praktik CSR, saat ini industri perbankan juga telah melampirkan aspek pertanggungjawaban sosial dalam laporan tahunannya walaupun dalam format standar." Prajarto, 2012. Seperti yang telah disinggung sebelumnya, CSR berlaku untuk semua perusahaan, tidak terkecuali perusahaan perbankan. Industri perbankan di Indonesia, menurut Mulyanita (2009), "Pengungkapan laporan CSR perusahaan karena adanya perubahan sudut pandang pertanggungjawaban dari manajemen ke shareholders menjadi manajemen ke stakeholders." Namun, ada satu jenis bank yang idealnya mempunyai perhatian lebih terhadap CSR, yaitu bank syariah. Hal ini dikarenakan bank syariah mempunyai nilai-nilai spiritual yang dominan jika dibandingkan dengan bank konvensional, yaitu nilai-nilai spiritual Islam. Nilai-nilai atau dimensi spiritual ini, tidak hanya menghendaki bisnis yang bebas riba, namun juga mampu menawarkan dan memberikan kesejahteraan bagi masyarakat luas, terutama masyarakat ekonomi lemah (Meutia, 2010).

Perbankan syariah merupakan sektor yang patut diperhitungkan. Walaupun perbankan syariah di Indonesia tercatat tumbuh dengan signifikan, namun jika disandingkan dengan perbankan konvensional porsi pasar perbankan syariah masih relatif kecil ukurannya yaitu sebesar 4,2\% (Bank Indonesia, 2012). Akan tetapi peluang industri perbankan syariah di masa datang diyakini akan semakin bagus dan patut diperhitungkan. Biro riset info bank (birI) mencatat dalam 5 tahun terakhir pertumbuhan rata-rata aset perbankan syariah melampaui pertumbuhan rata-rata aset industri perbankan nasional. Sejak 2007 hingga 2012, aset perbankan syariah rata-rata tumbuh $39,96 \%$ per tahun. Sementara dengan periode yang sama aset industri perbankan nasional rata-rata tumbuh $16,61 \%$ per tahun (Infobank, 2013). 
Menurut Meutia (2010) faktor penting yang mendasari didirikannya bank syariah adalah adanya kebutuhan dan kewajiban untuk menjalankan sistem perekonomian berdasarkan nilai-nilai dan prinsip syariah, salah satunya adalah pelarangan riba. Riba merupakan aktivitas yang diharamkan dalam Islam karena dapat merusak masyarakat, dan dapat menyebabkan kesenjangan dalam bidang ekonomi dan sosial (Meutia, 2010). Menurut Yusuf (2010: 99), "kedudukan bank syariah sebagai institusi keuangan yang sudah eksis di taraf nasional maupun internasional harus menjadi lembaga keuangan yang dapat menjadi contoh teladan dalam menggerakan program CSR". Hal ini dikarenakan bank syariah merupakan lembaga keuangan yang menjalankan aktivitasnya berdasarkan pada filosofi dasar Al-Qur'an dan Sunah. Hal inilah yang menjadi dasar bagi pelakunya dalam berinteraksi dengan lingkungan dan sesamanya.

Sejalan dengan hal tersebut Undang-undang (UU) Nomor 21 Tahun 2008 tanggal 16 Juli 2008 tentang perbankan syariah secara khusus telah menegaskan kembali mengenai pentingnya fungsi sosial perbankan syariah. Hal ini diatur dalam Bab II mengenai asas, tujuan dan fungsi, khususnya pasal 4 ayat (2) sampai ayat (4) UU perbankan syariah. Fungsi ini melekat pada operasional yang dilakukan oleh setiap bank syariah. Keberadaan UU perbankan syariah yang memuat fungsi sosial bank syariah, menjadi landasan hukum positif yang semakin mempertegas peran dan fungsi perbankan syariah dalam aspek sosial. Artinya fungsi perbankan syariah selain memberikan fungsi kemanfaatan ekonomi juga memberikan fungsi manfaat sosial bagi masyarakat.

Haniffa dan Hudaib (2004) menyatakan bahwa, "pengungkapan informasi yang relevan dan dapat diandalkan dalam laporan tahunan merupakan salah satu cara untuk menunjukkan tanggungjawab dan komitmennya dalam memenuhi kebutuhan umat Islam dan masyarakat secara umum. Melalui pengungkapan tanggungjawab sosial bank syariah dapat memberikan informasi sejauh mana ia telah memenuhi fungsi sosialnya." Bank syariah harus mengungkapkan informasi yang penting bagi para pengguna laporan mereka guna pengambilan keputusan untuk menunjukkan tanggungjawab mereka pada Tuhan dan masyarakat, hal ini jelas jauh berbeda dengan bank konvensional yang cenderung menekankan pada pengungkapan laba, penilaian resiko, dan aspek nonsosial lainnya,

Ada beberapa penelitian yang dilakukan terkait CSR di dunia perbankan, salah satunya telah diteliti oleh Othman dan Thani (2009) yang mengembangkan indeks pengungkapan yang relevan dengan hal-hal yang telah disebutkan sebelumnya pada ISR, kemudian ia kembangkan secara lebih ekstensif dengan obyek penelitian perusahaan yang terdaftar di dalam bursa efek Malaysia, dan hasilnya adalah laporan sosial yang dilakukan oleh perusahaan-perusahaan tersebut masih minim. Hal ini mengindikasikan bahwa perusahaan-perusahaan pada umumnya masih memfokuskan pada laporan keuangan yang mereka anggap memberikan keuntungan lebih bagi perusahaan. Meskipun perusahaan-perusahaan itu telah mempublikasikan laporan sosialnya, namun hal tersebut bisa dikatakan sebagai pelengkap, ataupun hanya untuk memenuhi regulasi pemerintah. Kemudian ada Hasan dan Harahap (2010) yang juga melakukan penelitian tentang pengungkapan CSR terhadap perbankan syariah yang ada di Malaysia. Mereka menggunakan laporan tahunan dari tujuh perbankan syariah, dengan metode 
content analysis. Hasilnya menunjukkan bahwa satu dari tujuh bank syariah indeks pengungkapan CSRnya berada di atas rata-rata dan isu-isu CSR belum menjadi perhatian utama bagi sebagian besar bank syariah yang ada di Malaysia.

Berikutnya adalah Purwitasari dan Chariri (2011) yang menganalisis pengungkapan laporan sosial yang ada pada dua bank syariah, yaitu Bank Muamalat dan Bank Mandiri syariah. Dengan menggunakan data laporan sosial Bank Muamalat dan Bank Mandiri syariah tahun 2010, didapatkan temuan bahwa Bank Muamalat dan Bank Mandiri syariah tidak seluruh item laporan sosialnya berdasarkan shariah enterprise theory (SET). SET merupakan pengembangan dari enterprise theory yang telah diinternalisasi dengan nilai-nilai Islam guna menghasilkan teori yang transendental dan lebih humanis (Purwitasari, 2011). Shariah Enterprise Theory menurut Triyuwono (2012), memiliki pandangan bahwa distribusi kekayaan atau nilai tambah tidak hanya berlaku kepada pihak perusahaan saja akan tetapi juga kepada masyarakat (stakeholders). Dari temuan tersebut tentunya dapat membuat kita untuk menyadari bahwa ada beberapa faktor atau penyebab yang membuat laporan sosial bank syariah belum sepenuhnya memenuhi prinsip-prinsip syariah. Disadari atau tidak, faktor regulasi, tujuan laporan sosial, serta peruntukkan laporan sosial memberikan pengaruh yang cukup besar dalam membuat laporan sosial.

Selanjutnya penelitian yang bertemakan analisis semiotika dilakukan oleh Yussof dan Lehman (2009). Penelitian ini dilakukan terhadap laporan sosial 50 perusahaan publik yang ada di Malaysia dan Australia dengan menggunakan analisis semiotika. Penelitian tersebut menghasilkan temuan bahwa pengungkapan laporan sosial yang dilakukan oleh perusahaan publik di Malaysia dan Australia mempunyai kesamaan motif, yaitu informasi sosial yang disajikan merupakan sebuah strategi perusahaan untuk meningkatkan reputasi baik perusahaan.

Dari beberapa penelitian-peneltian yang telah disebut di atas, dapat diambil kesimpulan bahwa pelaporan atau pengungkapan CSR yang dilakukan oleh perusahaan masih dianggap sebagai alat untuk membentuk citra perusahaan semata yang ujungnya akan menguntungkan pihak perusahaan, dan juga pengungkapan CSR masih dianggap sebagai pelengkap dalam laporan tahunan yang dirilis oleh perusahaan, sehingga apa yang sudah menjadi tanggungjawab perusahaan kepada lingkungan dan sosial masih terabaikan. Dan mitos-mitos tersebutlah yang masih beredar di dalam masyarakat tentang kegiatan CSR.

\section{METODE PENELITIAN}

Pada penelitian ini, dihasilkan data deskriptif berupa kata-kata tertulis yang bersumber dari narrative text pada pelaporan keuangan bank syariah periode 2010 - 2012, dengan fokus pada laporan sosial (CSR). Karena bentuk kegiatan corporate social responsibility yang dijalankan dalam bank syariah akan lebih mudah dipahami dengan cara mempertimbangan prinsip atau nilai Islam yang digunakan, dan struktur organisasi, serta faktor-faktor eksternal lainnya yang mempengaruhi dipraktekkannya dan diungkapkannya kegiatan corporate social responsibility yang menjadi bagian penting untuk dianalisis dan diamati. 
Penelitian ini merupakan penelitian kualitatif dengan menggunakan analisis semiotik sebagai cara untuk memahami dan memaknai laporan sosial bank syariah. Dalam KBBI, semiotik mempunyai pengertian sebagai ilmu tentang lambang dan tanda. Menurut Hoed (2008), "semiotik adalah ilmu yang mengkaji tanda dalam kehidupan manusia." Sedangkan Muzakki (2007) mengemukakan bahwa, "Semiotika merupakan salah satu model ilmu pengetahuan sosial yang bertujuan untuk mengenali dunia sebagai sistem hubungan yang memiliki unit dasar yang disebut tanda." Tanda yang dimaksud di sini adalah segala sesuatu di mana seorang manusia bisa memberikan makna atas tanda tersebut. Tanda-tanda tersebut dapat diinterpretasikan melalui pemahaman yang umum seperti makna yang sederhana dan biasanya didasarkan pada bahasa yang biasa digunakan oleh masyarakat (Yusoff dan Lehman, 2009). Sehingga dapat disimpulkan bahwa ilmu semiotika ini menganggap fenomena sosial atau masyarakat dan kebudayannya merupakan tanda-tanda (Muzakki, 2007).

Lain lagi dengan Yasraf Amir Piliang ${ }^{1}$ menyebutkan bahwa semiotika merupakan sebuah ilmu yang dinamis, lentur dan terbuka bagi pelbagai bentuk dan interpretasi. Dan, logika interpretasi bukanlah logika matematika, yang hanya mengenal kategori salah dan benar. Namun, logika atau nalar semiotika adalah nalar di mana interpretasi tidak dipahami berdasarkan benar atau salah, melainkan derajat kelogisannya, dengan kata lain akan ada interpretasi yang lebih masuk akal dari yang lainnya. Dengan kata lain semiotika berperan untuk melakukan interogasi terhadap simbol-simbol atau teks yang digunakan oleh penulis agar pembaca bisa menyelami bilik-bilik makna yang tersimpan di dalamnya (Vera, 2014).

Ahli semiotika Roland Barthes mengemukakan bahwa semiotika pada dasarnya hendak mempelajari bagaimana kemanusiaan (humanity) memaknai sesuatu (things) (Sobur, 2013). Dan salah satu area penting yang ditambahkan Barthes dalam studinya tentang tanda adalah peran pembaca (Muzakki, 2007). Barthes, dalam bukunya yang berjudul The Death Author meyatakan bahwa dalam memahami atau memaknai teks diserahkan sepenuhnya kepada pembaca, yang artinya bahwa setelah teks diciptakan oleh penulis maka penulis teks dianggap mati (Vera, 2014). Barthes adalah penerus pemikiran Saussure, dia meneruskan pemikiran tersebut dengan menekankan pada interaksi teks dengan pengalaman pribadi dan budaya penggunanya. "Bila Saussure hanya menekankan pada penandaan dalam tataran denotatif, maka Barthes menyempurnakan semiologi Saussure dengan mengembangkan sistem penandaan pada tingkat konotatif." Vera, 2014. Gagasan Barthes ini dikenal dengan "order of signification". Dalam "order of signification" tersebut Barthes mengembangkan dua tingkatan pertandaan yang mempunyai kemungkinan untuk menghasilkan makna yang bertingkat-tingkat, yaitu tingkat denotasi dan konotasi (Piliang, 2010).

\footnotetext{
${ }^{1}$ Yasraf Amir Piliang merupakan seorang filsuf, pemikir, kebudayaan, akademisi, dan pengamat sosial. Ia juga merupakan pendiri Yasraf Amir Piliang Institute, sebuah lembaga yang mengkaji kebudayaan kontemporer.
} 
Menurut Piliang (2010) denotasi adalah tingkat antara tanda dan rujukannya pada realitas, atau pertandaan yang menjelaskan hubungan antara penanda dan petanda, dan menghasilkan makna yang eksplisit, langsung dan pasti. Vera (2014) menyatakan penanda adalah bentuk-bentuk medium yang diambil oleh suatu simbol, seperti sebuah gambar, bunyi, atau goresan yang membentuk kata di suatu halaman, sedangkan petanda adalah konsep dan maknamakna. Selanjutnya makna konotasi adalah tingkat pertandaan yang didalamnya terdapat makna yang tidak eksplisit, tidak langsung, dan tidak pasti (terbuka untuk segala kemungkinan), yang menjelaskan hubungan antara penanda dan petanda,. Terbentuknya makna konotatif ini dipengaruhi berbagai aspek, misalnya aspek psikologis, seperti emosi, perasaan atau keyakinan. Tingkatan tanda dan makna Barthes dapat digambarkan sebagai berikut:

\section{Gambar 3.1:}

Tingkatan tanda dan Makna Barthes

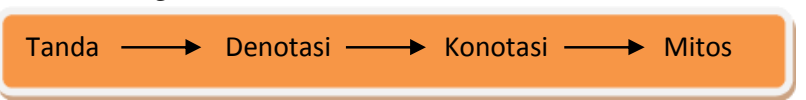

Dalam semiotika Barthes, konotasi lebih identik dengan mitos dan bertujuan untuk mengungkapkan dan memberikan pembenaran bagi nilai-nilai dominan yang berlaku dalam suatu periode tertentu (Vera, 2014). Dalam penelitian ini untuk menggali mitos yang ada dalam laporan sosial dibutuhkan wawancara. Informan yang digunakan dalam penelitian ini adalah nasabah dari bank syariah, hal ini menurut peneliti karena informan tersebut mempunyai pengetahuan dan pengalaman selama menjadi nasabah.

Data yang digunakan dalam penelitian ini adalah laporan tahunan yang dirilis oleh bank syariah periode 2010-2012. Metode yang digunakan untuk pengumpulan data yaitu metode dokumentasi dengan mencatat data yang didapat dari laporan, catatan dan arsip dari beberapa sumber misalnya, website resmi Bank syariah, jurnal, penelitian terdahulu dan sumber lain yang relevan. Untuk memperoleh data yang lebih lengkap dan akurat, peneliti juga melakukan wawancara dengan pihak atau informan yang relevan dengan masalah penelitian.

"Teknik analisis data merupakan proses pengelolaan dan pengaturan secara sistematik data ke dalam pola, kelompok, dan satuan uraian dasar sehingga dapat ditemukan tema dan hipotesis kerja seperti yang disarankan, dan untuk meningkatkan pemahaman terhadap bahan-bahan tersebut untuk dipresentasikan kepada orang lain," Moleong, 2006: 103. Dalam penelitian ini, peneliti menggunakan semiotika Barthes sebagai alat analisisnya, yaitu dengan mengumpulkan data dari laporan sosial baik teks maupun gambar berdasarkan makna konotatif dan denotatifnya.

Kegiatan sosial atau CSR bank syariah dilaksanakan oleh Baitulmaal bank syariah sebagai kepanjangan tangan dari Bank syariah. Dalam laporan sosial Bank syariah terdapat lima aspek utama yang dilaporkan, yaitu, pemberdayaan ekonomi, pendidikan, sosial, Non-ZIS, dan wakaf. Dari kelima tema tersebut masing-masing terdapat berbagai kegiatan yang dilakukan oleh Bank syariah, kemudian peneliti akan menganalisis masing-masing tema tersebut dengan menggunakan semiotika. 
Sementara itu penelitian awal yang dilakukan oleh peneliti menunjukkan bahwa Bank syariah dalam menyusun laporan CSR nya belum menggunakan standar tertentu. Hal ini dibuktikan dengan tidak adanya informasi yang tercantum baik dalam laporannya maupun dalam website resmi Bank syariah dan website resmi Baitulmaal bank syariah. Untuk memperoleh informasi mengenai standar yang digunakan, peneliti melakukan wawancara dengan pihak Baitulmaal bank syariah yang difasilitasi oleh Bapak NJ selaku staf Departemen Sosial dan Kemanusiaan. Dari keterangan yang disampaikan oleh Bapak NJ, didapatkan informasi bahwa bank syariah mengembangkan sendiri standar pelaporan CSR nya, yaitu ISO 9001:2008. ISO 9001 merupakan standar sistem kualitas manajemen yang bertujuan untuk menjaga kepuasan konsumen, serta ISO ini telah didesain agar dapat digunakan oleh semua organisasi, baik yang bergerak dalam bidang produk maupun jasa. ISO 9001 menyediakan seperangkat aturan yang ditujukan untuk mengoperasikan sistem manajemen yang berkualitas. Namun, dari informasi serta penjelasan tentang ISO tersebut, peneliti mengindikasikan bahwa Bank syariah dalam menyusun laporan sosialnya tidak menggunakan standar pelaporan sosial yang baku. Sehingga peneliti menggambarkan alur penelitiannya sebagai berikut:

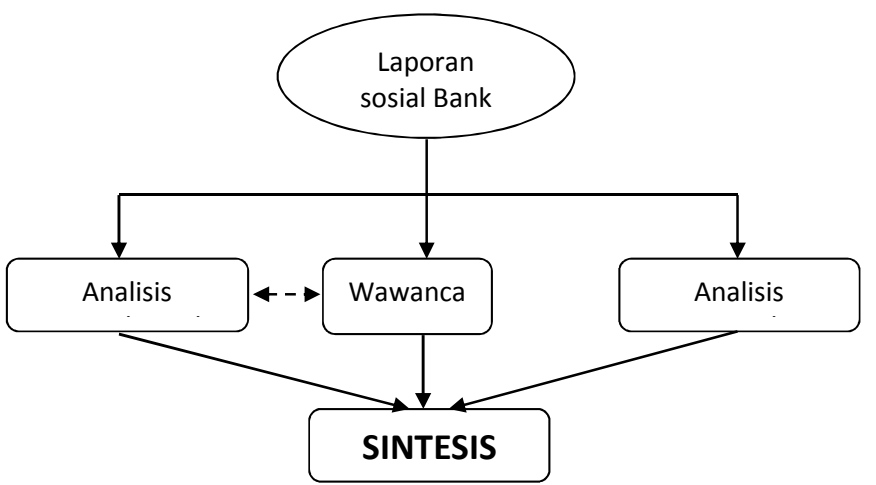

Gambar: 3.2 Alur Penelitian

Informan yang digunakan dalam penelitian ini adalah staf dari pihak Baitulmaal bank syariah yang berada dalam Departemen Sosial Kemanusiaan, Selain itu peneliti juga menggunakan informan dari pihak nasabah bank syariahn yang diwakili oleh YB dan AP. Wawancara ini diperlukan untuk membuktikan mitos yang ada dalam CSR bank syariah. Adapun identitas informan dapat dilihat pada tabel berikut: 
Tabel 3.1 Identitas Informan

\begin{tabular}{llc}
\multicolumn{1}{c}{ Informan } & Entitas & Jabatan \\
Bapak NJ & Bank Syariah & Staf \\
YB & Nasabah & - \\
AP & Nasabah & -
\end{tabular}

\section{HASIL PENELITIAN}

Penelitian yang menggunakan data selama kurun waktu tiga tahun ini menghasilkan analisis yang tidak jauh berbeda dari ketiga tahun pelaporan. Namun, ketiga laporan tersebut mempunyai perbedaan di sisi format laporannya.

Pada laporan sosial Bank syariah periode 2010 terdapat empat (4) lembaga yang diberi kepercayaan oleh Bank syariah Indonesia untuk mengelola dana serta melaksanakan kegiatan sosial. Ke empat lembaga tersebut adalah pertama, Baitulmaal bank syariah dengan delapan (8) program kegiatan yang dilakukan, yaitu, pemberdayaan ekonomi, santunan pendidikan, santunan sosial dan kemanusiaan, santunan kesehatan, CSR, program Non-ZIS, dan yang terakhir adalah pemberdayaan wakaf. Kedua, Ikatan Cendekiawan Muslim se-Indonesia (ICMI), dengan lima (5) program kegiatan, yaitu, program agroforesty, pelatihan wirausaha, kajian konsolidasi ekonomi, national leadership training, dan program pendidikan dan pemberdayaan perempuan. Sedangkan yang terakhir adalah Yayasan Dana Dakwah Pembangunan (YDDP) dan Majelis Ulama Indonesia (MUI), dengan beberapa kegiatan, sosialisasi perbankan syariah, kegiatan kerjasama internasional dengan beberapa negara asing, bimbingan rohani bagi narapidana, penyuluhan ibadah \& bimbingan keagamaan bagi TKI/TKW, dan penerbitan fatwa MUI oleh komisi fatwa MUI. Dalam bab ini, peneliti menyajikan tafsir teks dari masing-masing program yang telah disebutkan dalam laporan sosial. Dalam laporan sosial Bank syariah periode 2011 ini, terdapat banyak perbedaan jika dibandingkan dengan laporan sosial pada periode 2010. Diantaranya, dalam laporan sosial periode 2011 terdapat struktur organisasi baitulmaal, pengerucutan pembagian program sosial, dari tujuh (7) program di tahun 2010 menjadi lima (5) program di tahun 2011, terdapat informasi penerimaan sumber dana sosial, dan informasi distribusi dana sosial. Di dalam laporan sosial periode 2012 ini, Bank syariah menyajikan dengan lebih sederhana jika dibandingkan dengan tahun-tahun sebelumnya. Peneliti akan mengawalinya dengan menganalisis laporan sosial pada program kegiatan tahunan, yang kemudian dilanjutkan dengan program kegiatan sosial serta program khusus.

Peneliti akan kilas balik ke laporan sosial bank syariah di tahun 2010 . Tahun 2010 merupakan awal prestasi bank syariah di bidang CSR yang ditandai dengan memperoleh penghargaan Best Empowerment in Economic Program dari IMZ Award (Indonesia Magnificence of Zakat) dan sebagai 3rd Rank "The Best 
Lembaga Amil Zakat Nasional" dari lembaga Islamic Social Responsibility (ISR) Award. Penghargaan-penghargaan tersebut merupakan bukti kesuksesan bank syariah dalam menjalankan program CSR-nya. Hal ini tidak terlepas dari campur tangan baitulmaal sebagai pihak yang mempunyai wewenang dalam menentukan dan melaksanakan kegiatan-kegiatan CSR bank sebagaimana yang diungkapkan oleh Pak NJ.

Program CSR merupakan program yang dilakukan untuk memberikan manfaat bagi masyarakat dan lingkungan. Agar masyarakat juga tahu tentang keberlangsungan program CSR yang dilakukan oleh perusahaan, maka perlu adanya sebuah media yang memuat seluruh kegiatannya, yaitu melalui sebuah laporan sosial. Media ini dapat menjembatani komunikasi antara perusahaan dan masyarakat. Laporan sosial ini berisi informasi yang tersaji dalam bentuk teks, tabel, dan juga gambar. Perusahaan sebagai penyedia informasi, sedangkan masyarakat sebagai penerima dan pengguna informasinya.

Di dalam laporan sosial 2010, dijelaskan sekilas tentang profil Baitulmaal bank syariah sebagai kepanjangantangan dari bank syariah itu sendiri dalam melaksanakan kegiatan CSR, disertai dengan visi dan misinya. Baitulmaal bank syariah merupakan lembaga yang mempunyai wewenang dalam mengelola dan melaksanakan kegiatan CSR bank syariah tersebut. Dari sini sudah terlihat bahwa bank syariah berupaya profesional dalam menjalankan program CSR-nya karena kemanfaatannya tidak hanya untuk masyarakat akan tetapi juga menyangkut nama baik perusahaan. Hal ini sejalan dengan Perbawani (2012) yang menyatakan bahwa corporate social responsibility juga dapat dikatakan sebagai sebuah program atau cara yang dapat digunakan untuk mengkomunikasikan esksistensi perusahaan kepada masyarakat luas.

Ada berbagai macam kegiatan sosial yang dilaksanakan sepanjang tahun 2010, dan juga ada kerjasama yang terjalin antara bank syariah dengan ICMI, YDDP dan MUI. Ketiga lembaga tersebut merupakan lembaga Islam besar di Indonesia, yang mempunyai kredibilitas baik di mata masyarakat. Dengan adanya kerjasama tersebut dapat membuka peluang bagi perusahaan untuk memperluas program CSR serta wilayah distrubusinya. Yang menjadi nilai lebih di sini adalah dapat menunjukkan ke masyarakat bahwa bank syariah dalam menjalankan kegiatan CSR-nya tidak setengah-setengah, perusahaan berupaya untuk selalu menjalankan prinsip-prinsip syariah yang dianutnya. Tidak ada hal yang lebih baik dibanding ketika perusahaan dapat membuktikan dirinya bahwa syariah bukan hanya sebagai simbol semata. Namun, tidak dapat dipungkiri juga bahwa prinsip syariah masih menjadi daya tarik tersendiri bagi masyarakat. Seperti yang diungkapkan oleh AP, dia berpendapat bahwa alasan untuk menjadi nasabah adalah karena sifat syar'i dan dapat memberikan pendidikan dini tentang pengelolaan uang yang baik secara Islam kepada putranya. Begitu pula dengan $Y B$ yang tertarik menjadi nasabah bank syariah ini dikarenakan label syariah yang melekat pada bank tersebut.

Untuk mempertegas laporan sosialnya, bank syariah juga menampilkan beberapa foto dokumentasi kegiatan CSR yang tersebar di laporan sosial 2010. Foto dapat menjadi bukti penting perusahaan dalam mempertanggungjawabkan kegiatan CSR. Karena dengan foto dapat menambah keyakinan pembaca akan 
fakta kegiatan CSR perusahaan. Dalam foto terdapat pula simbol-simbol yang mengandung makna di dalamnya, baik dari bentuk, ekspresi dan warna. Perusahaan berusaha menampilkan identitasnya di setiap foto yang di tampilkan, yaitu dengan memberi warna ungu yang dominan di setiap fotonya. Tanpa harus berpikir panjang, pembaca akan tahu bahwa ungu adalah warna kebesaran dari bank syariah itu sendiri.

Pada tahun 2011, bank syariah mencapai usia yang ke-20 tahun. Usia yang tidak bisa dibilang muda bagi sebuah entitas bisnis. Melalui laporan sosial, perusahaan berupaya untuk menunjukkan kedewasaannya, hal ini dapat dilihat dari bentuk laporannya dan jenis kegiatannya. Laporan sosial 2011 bank syariah disusun dengan format lebih rapi dan ringkas, sehingga memudahkan pembaca untuk memahaminya, hal ini jauh berbeda dengan laporan sosial periode sebelumnya. Menurut peneliti ada dua hal menarik dari laporan sosial 2011, yaitu kegiatan milad 20 tahun bank syariah dan kampanye go green.

Dengan mengusung tema pengadaan 100 bedug bagi musholla dan masjid yang belum memilikinya, ini menandakan bahwa perusahaan ingin membagi kebahagiannya melalui kegiatan tersebut. Pencapaian ini tentunya memerlukan usaha dan strategi yang bagus supaya dapat bertahan ditengah ketatnya persaingan. Sikap baik perusahaan terhadap masyarakat sebagai konsumen akan melahirkan respon balik dari masyarakat yang bermuara pada reputasi positif perusahaan (Perbawani, 2012). Oleh karena itu sebagai ajang pembuktian kepada masyarakat dan kompetitornya, bank syariah menjadikan angka 100 sebagai penanda kesempurnaan perusahaan di usianya yang ke-20. Dan bedug sebagai simbol relijius yang diusung agar dapat memperoleh kesan syariah.

Kegiatan CSR merupakan kegiatan yang mempunyai karakteristik berbeda dengan kegiatan bisnis. Kegiatan ini lebih mengedepankan sisi sosial perusahaan. Pada umumnya yang melaksanakan kegiatan CSR yang berhubungan dengan alam adalah perusahaan manufaktur. Namun, melalui program kampanye go green-nya bank syariah berusaha mendobrak anggapan tersebut. Sebagai entitas yang bergerak di dunia perbankan, bank syatiah membuktikan kepada masyarakat bahwa mereka juga mempunyai kepedulian terhadap kelestarian alam.

Kegiatan-kegiatan sosial yang terdokumentasi ke dalam foto-foto di tata sedemikian rupa agar memudahkan pembaca untuk melihatnya. Foto-foto dalam laporan sosial 2011 memiliki kualitas gambar yang lebih baik, sehingga dapat memberikan gambaran jelas tentang kegiatan yang telah dilakukan. Selain itu warna dominasi warna ungu tetap terlihat namun ada satu tambahan warna hijau di dalamnya. Menurut peneliti hadirnya warna hijau ini untuk mengimbangi warna ungu yang sebelumnya telah ada. Ungu mempunyai makna spiritual, kemakmuran dan kreativitas, sedangkan hijau bermakna perenungan, kepercayaan (agama), dan keabadian (Darmaprawira, 2002). Jika keduanya disandingkan maka akan terbentuk suatu makna bahwa perusahaan merupakan sebuah entitas yang bernafaskan spiritual dan dapat memegang amanah untuk memberikan kemakmuran kepada masyarakat. Sehingga warna-warna tersebut dapat mendukung jati diri perusahaan ke hadapan masyarakat.

Penghargaan-penghargaan yang mereka peroleh sebelumnya merupakan bukti keberhasilan perusahaan dalam menjalankan kegiatan CSR. Tentunya perusahaan 
juga berusaha untuk tetap menjaga prestasinya, karena hal tersebut membawa nama baik perusahaan di mata masyarakat.

Lebih lanjut lagi pada laporan sosial 2012, perusahaan lebih menunjukkan taringnya lewat kegiatan-kegiatan yang mereka laksanakan. Salah satunya adalah menggandeng Band Wali dalam pelaksanaan Idul Adha. Selain sebagai penyemarak dalam merayakan Idul Adha, tentunya Band Wali juga mempunyai daya tarik tersendiri bagi perusahaan. Dengan prestasinya di dunia musik sebagai band yang mengusung tema relijius tentunya hal ini mampu mendorong kualitas perusahaan dalam pelaksanaan kegiatan CSR. Tidak hanya sekedar melaksanakan CSR, akan tetapi juga berupaya memberikan dakwah lewat nada dan lagu. Upaya ini sekiranya dapat menjadi indikasi bahwa bank syariah tetap menjaga eksistensinya bagi keberlangsungan perusahaan. Hal yang serupa juga dirasakan oleh informan YB bahwa bank syariah tidak hanya sebagai entitas bisnis tapi juga sebagai entitas dakwah dan sosial, yang mempunyai tanggungjawab moral kepada masyarakat.

Makna-makna tersebut muncul melalui semiotika Barthes, yang memandang teks dari dua sudut yaitu denotatif dan konotatif. Tentu saja dari sudut denotatif, bank syariah beserta baitulmaal telah melaksanakan kegiatan CSR dengan baik. Dengan segala kemampuan dan usahanya mereka berusaha memberikan yang terbaik untuk masyarakat. Namun, tidak dapat dipungkiri juga bahwa laporan sosial yang disusun oleh perusahaan juga mempunyai tujuan yang lain. Seperti halnya yang telah diungkapkan oleh informan dari pihak nasabah yang berinisial $Y B$, mengatakan bahwa manfaat CSR lebih besar sebagai pencitraan, laporan yang disediakan hanya untuk menarik nasabah. Lebih lanjut informan mengungkapkan bahwa nasabah juga ikut menyumbang dalam kegiatan CSR, dan hal ini sebenarnya tidak jauh beda dengan undian berhadiah di bank, akan tetapi menurut informan kemanfaatannya lebih baik di wujudkan melalui program CSR. Paling tidak melalui program CSR, selain untuk mendapatkan keuntungan bagi perusahaan tetapi juga memberi manfaat pada masyarakat. Menjaga imej positif dan menarik konsumen atau nasabah telah melekat di dalam tujuan kegiatan CSR. Tidak dapat dipungkiri bahwa masyarakat tidak bisa membedakan apakah peningkatan prestasi perusahaan itu merupakan tujuan program CSR ataukah efek samping dari program tersebut. Selain sebagai ajang pembuktian diri kepada masyarakat dan kompetitor, juga sebagai media promosi untuk menarik nasabah. Makna-makna yang muncul tersebut juga didukung oleh informasi yang diperoleh dari pihak bank maupun nasabah. Secara singkat peneliti dapat menjelaskan bahwa apa yang telah dilakukan oleh perusahaan terkait program CSR merupakan salah satu cara untuk menciptakan, membangun dan mempertahankan imej positifnya di mata masyarakat dan shareholders-nya.

\section{KESIMPULAN}

Analisis teks laporan sosial yang telah dilakukan oleh peneliti pada babbab sebelumnya mengungkapkan tentang pemaknaan dan pemahaman laporan sosial bank syariah dengan menggunakan semiotika Barthes, dan didukung oleh 
hasil wawancara dengan informan dari pihak baitulmaal dan nasabah. Makna dan pemahaman yang diperoleh peneliti pada laporan sosial tahun 2010, 2011 dan 2012 adalah mengindikasikan adanya tujuan lain dari diselenggarakannya kegiatan CSR oleh pihak perusahaan. Indikasi tersebut mengarah kepada tujuan untuk menciptakan, membentuk, dan mempertahankan sisi positif perusahaan di mata shareholders dan stakeholders. Menurut peneliti indikasi tersebut sama dengan mitos yang berkembang di masyarakat terkait kegiatan CSR, yaitu hanya sebagai media untuk mempertahankan sisi dan imej positif perusahaan.

Tidak dapat dipungkiri bahwa bank syariah yang mempunyai paradigma Islam juga merupakan sebuah entitas bisnis. Yang menjadi fokus utama dalam kegiatan bisnis adalah mencapai keuntungan yang maksimal dengan modal minimum. Selain itu perusahaan juga harus bersaing dengan kompetitorkompetitor yang sejenis di bidangnya. Dari sinilah akan muncul strategi-strategi bisnis untuk mempertahankan serta meningkatkan prestasi perusahaan. Salah satunya melalui kegiatan CSR. Dengan bersembunyi dibalik kepentingan sosial dan masyarakat, perusahaan dapat menciptakan pengaruhnya ke masyarakat. Pengaruh tersebut yang nantinya akan digunakan oleh perusahaan untuk menarik masyarakat agar menjadi nasabahnya. Peningkatan nasabah dapat mempengaruhi peningkatan profit yang diperoleh. Menurut peneliti hal inilah yang menjadi salah satu jalan aman dan halus untuk mencapai tujuan bisnis perusahaan.

Selain itu, menurut peneliti ada beberapa tantangan yang harus dihadapi oleh bank syariah sebagai sebuah entitas bisnis, diantaranya adalah isu-isu yang berkaitan dengan politik. Politik tidak hanya sekedar berhubungan dengan partai maupun pemerintahan, namun regulasi-regulai yang berlaku di Indonesia juga dapat mempengaruhi arah dari sebuah entitas bisnis. Di mana regulasi tersebut dapat berpengaruh juga terhadap perkembangan perusahaan.

Lalu prinsip syariah yang melekat pada diri bank syariah apakah hanya sekedar simbol semata? Dari hasil analisis teks yang dilakukan oleh peneliti, prinsip syariah yang menjadi paradigma bank syariah dalam menjalankan bisnisnya belum sepenuhnya dilaksanakan. Namun menurut peneliti, bukan berarti bank syariah tidak menjalankan prinsip syariahnya sama sekali, hanya saja dalam kegiatan bisnisnya prinsip tersebut belum dijalankan seratus persen oleh perusahaan. Meskipun begitu simbol syariah masih menjadi daya tarik tersendiri bagi masyarakat muslim, terlepas itu dilaksanakan oleh perusahaan atau tidak. Bank syariah masih menjadi primadona dikalangan umat muslim, karena mereka mempunyai keyakinan bahwa bank syariah akan mengantar mereka kepada transaksi yang halal. Karena peneliti juga menyadari bahwa untuk pengembangan dan pelaksanaan bank syariah yang seratus persen syariah memerlukan proses dan waktu yang lama.

Bagaimanapun juga bank syariah sebagai entitas bisnis syariah, juga tidak bisa mengesampingkan tujuan utama dari bisnisnya. Selain dari produk-produk syariahnya, kegiatan CSR juga bisa menjadi media bagi bank syariah untuk menunjukkan jati dirinya sebagai bank syariah. Dengan mengusung programprogram CSR yang bernafaskan Islam, baik dari segi konsep kegiatannya ataupun dari penerima manfaat. 
Catatan akhir yang dapat dituangkan oleh peneliti berdasarkan analisis yang telah dilakukan adalah kegiatan CSR yang dikelola dan dilaksanakan oleh bank syariah melalui bauitulmaalnya merefleksikan tindakan menciptakan, membuat serta mempertahankan sisi positif perusahaan yang dibungkus oleh kegiatan CSR, dengan niat untuk mengambil dan menguasai hati masyarakat serta pangsa pasar bank syariah yang ada di Indonesia. Hal ini juga diindikasikan dengan informasi tentang ISO 9001:2008 yang digunakan bank syariah sebagai guideline dalam menyusun laporan sosialnya. Sejatinya ISO 9001:2008 bukanlah sebuah panduan untuk menyusun laporan sosial terlebih lagi bagi perbankan syariah. ISO 9001:2008 merupakan sebuah standar quality management yang didalamnya terdapat prinsip-prinsip yang berkaitan dengan fokus terhadap konsumen, motivasi dan implikiasi dari manajemen atas, proses pendekatan dan peningkatan yang berkelanjutan (www.iso.org). Menurut peneliti ISO dapat dijadikan tameng bagi perusahaan untuk 'melegalkan' laporan sosialnya. Karena dalam proses penyusunan sebuah laporan akan lebih baik jika terdapat panduan atau guidline yang harus diikuti. Sehingga dapat menghasilkan laporan yang konsisten dan dapat dipertanggungjawabkan.

Dalam sintesis hasil penelitian ini ditemukan satu benang merah antara laporan sosial tahun 2010, 2011, dan 2012, yaitu apa yang telah dituliskan oleh bank syariah mengenai laporan sosialnya merupakan refleksi dari niatan perusahaan dalam mempertahankan keberlangsungan kegiatan bisnisnya. Makna yang muncul dari analisis ala Barthes ini mengindikasikan bahwa melalui kegiatan CSR yang tercermin dalam laporan sosial, perusahaan berupaya untuk mengambil dan menguasai hati masyarakat serta pangsa pasar syariah dengan cara menciptakan dan mempertahankan sisi positifnya di mata masyarakat.

Kemasan kata-kata yang tersaji dalam laporan sosial dapat mengaburkan tujuan yang sebenarnya. Sehingga melalui sisi yang bertolak belakang dengan kegiatan bisnis inilah perusahaan dapat menarik perhatian masyarakat tanpa harus ada unsur pemaksaan. Dari hasil penelitian ini diharapkan bank syariah lebih mengedepankan manfaat kegiatan sosial terhadap masyarakat daripada manfaat yang berlebih bagi bank itu sendiri. Hal ini dikarenakan bank syariah merupakan bank yang berbasis hukum-hukum Islam yang lebih menonjolkan kemaslahatan umat dibandingkan dengan maximum profit.

\section{DAFTAR PUSTAKA}

Darmaprawira, W.A Sulasmi. (2002). Warna Teori dan Kreativitas Penggunaannya. ITB. Bandung.

Hassan, Abu \& Sofyan Syafri Harahap. (2010). Exploring Corporate Social Responsibility Disclosure: The case of Islamic Banks. International Journal of Islamic and Middle Eastern Finance and Management. Vol 3. No.3. Pp. 203-227.

Haniffa, Roszaini. (2002). Social Reporting Disclosure An Islamic Perspective. Indonesian Management \& Accounting Research. 1 (2). Pp. 128-146. 
Haniffa, Roszaini \& M. Hudaib. (2004). Disclosure Practice of Islamic Financial Institutions: An Exploratory Study. Working Paper at the Accounting Commerce and Finance. The Islamic Perspective International Conference $V$. Brisbone. Australia.

Hoed, Benny H. (2008). Semiotik dan Dinamika Sosial Budaya: Ferdinand de Saussure, Roland Barthes, Julia Kristeva, Jacques Derrida, Charles Sanders Peirce, Marcel Danesi \& Paul Perron, dll. Fakultas Ilmu Pengetahuan Budaya. Universitas Indonesia. Depok.

Kamus Besar Bahasa Indonesia. (2005). Departemen Pendidikan Nasional. Balai Pustaka. Jakarta.

Meutia, Inten. (2010). Shariah Enterprise Theory sebagai Dasar Pengungkapan Tanggungjawab Sosial untuk Bank Syariah. Tesis. Universitas Brawijaya. Malang.

Moleong, Lexy J. (2006). Metode Penelitian Kualitatif. Rosda. Bandung.

Mulyanita, Sugesty. (2009). Pengaruh Biaya Tanggung Jawab Sosial Perusahaan Terhadap Kinerja Perusahaan Perbankan. Universitas Lampung. Lampung.

Muzakki, Akhmad. (2007). Kontribusi Semiotika dalam Memahami Bahasa Agama. UIN-Malang Press. Malang.

Othman, Rohana \& Azlan Md Thani. 2010. Islamic Social Reporting of Listed Companies in Malaysia. International Business \& Economics Research Journal. Vol. 9. Number 4.

Perbawani, Pulung Setiosuci. (2012). Rantai Pemahaman Corporate Social Responsibility. CSR Indonesia Sinergi Pemerintah, Perusahaan dan Publik. Fisipol UGM. Yogyakarta.

Piliang, Yasraf Amir. (2010). Hipersemiotika: Tafsir Cultural Studies atas Matinya Makna. Jalasutra. Yogyakarta.

Prajarto, Nunung. (2012). Kepedulian dan Tanggung Jawab CSR dari Tumpukan Uang Bank. CSR Indonesia Sinergi Pemerintah, Perusahaan dan Publik. Fisipol UGM. Yogyakarta.

Priyanti, Efi. A. Kamayanti \& Soesilawati S. Atmadja. (2012). Kepedulian Lingkungan dan Sosial: Analisis semiotika dan Indeks Pengungkapan Laporan CSR. CSR Indonesia Sinergi Pemerintah, Perusahaan dan Publik. Fisipol UGM. Yogyakarta.

Purwitasari, Fadilla. (2011). Analisis Pelaporan Corporate Social Responsibility Perbankan Syariah Dalam Perspektif Shariah Enterprise Theory: Studi Kasus Pada Laporan Tahunan Bank Syariah Mandiri dan Bank Muamalat Indonesia. (eprints.undip.ac.id).

Sayekti dan Wondabio. (2007). Pengaruh CSR Disclosure Terhadap Earning Response Coefficient. Simposium Nasional Akuntansi X. Makasar.

Sobur, Alex. (2013). Semiotika Komunikasi. Remaja Rosdakarya. Bandung.

Sukoharsono, Eko Ganis. (2010). Metamorfosis Akuntansi Sosial Dan Lingkungan: Mengkonstruksi Akuntansi Sustanabilitas Berdimensi Spiritualitas.

Triyuwono, Iwan. (2012). Akuntansi Syariah: Perspektif, Metodologi, dan Teori. Rajawali Pers. Jakarta. 
Vera, Nawiroh. (2014). Semiotika dalam Riset Komunikasi. Ghalia Indonesia. Bogor.

Yusoff, Haslinda \& G. Lehman. (2009). Corporate Reporting Through The Lens of Semiotics. Asian Review of Accounting. Vol. 17. pp. 226-246.

Yusuf, Muhammad Yasir. (2010). Model Pelaksanaan CSR Bank Syariah: Kajian Empiris Pembiayaan Mikro Baitul Maal Aceh. La-Riba: Jurnal Ekonomi Islam. Vol. 4.

www.bankmuamalat.com

www.muamalatinstitute.com

www.baitulmaalmuamalat.org

www.iso.org 